\title{
Discussion on the Development of Vocational Education and Training Business Against the Background of Large-scale Production of Rural Cultivated Land
}

\author{
Jiancui Ma \\ Hunan Modern Logistics College \\ Changsha, China
}

\begin{abstract}
At present, against the background of the Chinese national poverty alleviation project, as well as the mass entrepreneurship and innovation, the rural production and management model has also undergone great changes. Large-scale production is replacing the original family workshop production. This paper mainly analyzes the characteristics of entrepreneurs returning from rural areas, and the current market demand for innovative entrepreneurs, and analyzes the problems and obstacles in rural innovation and entrepreneurship. Therefore, according to the characteristics of vocational education, the training business that vocational education should start is analyzed.
\end{abstract}

Keywords - innovative entrepreneurship; returning farmers; vocational training

\section{INTRODUCTION}

Poverty alleviation is an arduous task at the present stage in China. Against the background of the national precision poverty alleviation strategy and the slogan of "mass entrepreneurship and innovation", in recent years, there are more and more innovative and entrepreneurial projects in rural areas, including household contracting agriculture, forestry, aquaculture, etc. However, the lack of knowledge of migrant peasant-workers returning to their hometowns makes it necessary to carry on the business training.

\section{The CONNOTATION OF LARGE-SCALE PRODUCTION}

Marshall puts forward in the book "Principles of Economics": "The benefits of mass production are best seen in industry. The interests of large factories are: the further division of the use and reform of specialized agencies, procurement and sales, expertise and management." Marshall also discussed two ways to form economies of scale, that is, relying on the "internal economies of scale" of individual enterprises for the full and effective use of resources and the improvement of organizational and operational efficiency, and relying on the "external economies of scale" formed by multiple companies due to reasonable division of labor and joint and reasonable regional layout. He further studied the changing law of scale economic remuneration, that is, with the continuous expansion of production scale, the scale remuneration will be followed by three stages: increasing returns to scale, constant returns to scale, and decreasing returns to scale.

Another branch of traditional economies of scale theory is Marx's theory of economies of scale. In the first volume of "Das Kapital", Marx analyzed in detail the idea that the development of social labor productivity must be based on large-scale production and cooperation. He believes that large-scale production is an effective way to improve labor productivity and is the only way for modern industrial development. On this basis, "people can organize the division of labor and the combination of labor, can the production materials be saved due to large-scale accumulation, and can produce the labor materials that are suitable for common use according to their material properties, such as machine systems. People can also produce the enormous natural forces, and people can turn the production process into a scientific application in technology." Marx also pointed out that the expansion of production scale is mainly to achieve the following objectives:

- The combination of production, supply and marketing and the expansion of capital;

- Reducing production costs.

Obviously, Marx's theory and Marshall's discourse on "external economies of scale" and "internal economies of scale" have the same result. The neoclassical economics group starts from the marginal cost of production and believes that only when the marginal benefit equals the marginal cost can the enterprise be at the best size.

\section{CHARACTERISTICS OF THE TALENT TEAM IN RURAL INNOVATION AND ENTREPRENEURSHIP PROJECTS}

Rural innovation and entrepreneurship projects are mostly carried out with the support of the national precision poverty alleviation policy. The main group of returning hometown entrepreneurs is still returning farmers, only a 
small number of college students and agricultural science and technology personnel, as well as some staff of poverty alleviation units. When a small number of college students, agricultural science and technology personnel, and staff of poverty alleviation units are part of the main body of the entrepreneurship, they bring new ideas, new technologies, and new resources and markets to the countryside, changing traditional agricultural production and management and having brought hope to the countryside. But at the same time it has caused confusion and trouble for most returning farmers in innovation and entrepreneurship, and it is difficult to walk on the road of entrepreneurship in the absence of professional skills.

\section{CURRENT MARKET DEMAND FOR RURAL INNOVATIVE ENTREPRENEURS}

In the era of "Internet +", "Internet + modern agriculture" has also become a demand. Rural entrepreneurs need to understand market dynamics, policies and regulations and product promotion through "Internet + " means. The use of "Internet +" can build a rural e-commerce platform, effectively expand the market and effectively reduce costs. The use of "Internet +" means to optimize the rural industrial structure, enhance the efficiency of agricultural production, promote the modernization of agricultural development, and bring the agricultural exhibition into line with the market. In particular, there is an effective means for innovative and entrepreneurial products to enter the market. Therefore, higher requirements are placed on farmers who return to their hometowns for innovation and entrepreneurship.

\section{A. It Is Necessary to Have New Thoughts and Ideas}

It will be necessary to change the traditional agricultural production and management model and carry out large-scale production, as well as adjust the original agricultural product structure, and seek a more suitable product structure according to market demand and regional geographical environment, so that the output of agricultural products can be more popular. Finding more regionally-specific agricultural products to increase core competencies can prevent homogenized projects from reducing the risks of entrepreneurs.

\section{B. It Is Necessary to Understand New Production Techniques}

Large-scale production is the basis of new technology, technology entrepreneurship, and the demand for technical talent is the source of entrepreneurship. Technological innovation is the key to the success of the project.

\section{It Is Necessary to Be Sensitive to the Market}

Products are the product of the market, and the degree of market preference directly determines the success or failure of entrepreneurship. Innovation and entrepreneurship projects should meet market needs and should not follow suit.

\section{It Is Necessary to Understand Marketing and Promotion}

Returning home for business is different from home production, and exporting products to the market is the most crucial part. Product promotion skills and skills learning is also a requirement for returning entrepreneurs.

\section{CURRENT PROBLEMS IN RURAL INNOVATION AND ENTREPRENEURSHIP}

With the support of policies, rural household contracting has become more and more large-scale production, and has achieved certain results. But the following problems and obstacles are common:

\section{A. Project Homogenization}

The large-scale production is carried out to a certain extent with the support of the local government. It is supported and regulated by the regional government in the production project, and the project is homogenized. This makes the market fiercely competitive and is not conducive to the sustainable development of the industry. It also increases the risk of entrepreneurs.

\section{B. Insufficient Innovation and Low Technology Content}

From the current rural innovation and entrepreneurship projects, household contracted large-scale production is a form, with little change in production methods and skills. While more traditional production methods have been used, the scale benefits have not reached the expected goals. Modern technology is used less and does not have core technology.

\section{Lack of High-level Innovation and Entrepreneurial Talents}

High-level innovation and entrepreneurial talents and teams are the core strengths for promoting entrepreneurship to innovation. At present, rural migrant workers account for about $70 \%$ of rural entrepreneurs and entrepreneurs, which makes it not high in the level of innovation and entrepreneurship projects, low in technology and serious in homogenization.

\section{Lack of Marketing Talents}

Product promotion is an important part of entrepreneurship. Due to the limitations of knowledge, the understanding of the market, and the limitations of the network of interpersonal relationships, it has caused great obstacles in the promotion of products, so that many products cannot be launched into the market as soon as possible. For example, some fresh fruits with short shelf life will suffer huge losses due to the inability to find sales channels in time.

\section{DISCUSSION ON THE DEVELOPMENT OF VOCATIONAL EDUCATION AND TRAINING BUSINESS}

The responsibility of vocational education is to face employment and to train qualified personnel according to market demand. Therefore, vocational training for market 
employment personnel and increasing the quality of employment is also an unshirkable responsibility of vocational education. At present, regarding the return of migrant workers, vocational education should adopt corresponding training measures to help them innovate and step into a new level.

\section{A. Vocational Education Should Carry out Short-term Training on Innovation and Entrepreneurship According to Local Conditions}

For the short-term training of returning entrepreneurs to carry out innovation and entrepreneurship, it will be necessary to introduce some innovative entrepreneurial projects and the general model of project implementation to help innovative entrepreneurs choose more suitable entrepreneurial projects. It will also be necessary to introduce theoretical knowledge related to innovation and entrepreneurship, as well as theoretical knowledge and necessary professional skills related to innovative entrepreneurship projects.

\section{B. Targeted Professional Skills Training}

Training in the expertise and skills of village-style projects can be carried out. Vocational training into the village is a relatively effective way. Migrant workers returning to their hometowns should be weak in learning. The effect of studying in the classroom cannot be achieved. If the village-based on-site teaching is adopted, it will not only have strong pertinence, but also achieve training effects and even be able to solve some problems encountered during the actual work.

\section{Regularly Conducting Common Training Courses}

Once large-scale production is adopted, technology will be the key, but it will also face management and market. Programmatic and systematic management knowledge training for returning entrepreneurs, regular market situation feedback, marketing knowledge training, as well as existing marketing skills and new ways of training, makes it possible for innovative entrepreneurs to connect with the market and promote product promotion.

\section{CONCLUSION}

Large-scale production brings economies of scale to the production of agricultural products, which increases production. However, due to the current low quality of the entrepreneurial team, it also brings many troubles and obstacles in the production and operation process. Improving the overall quality of the entrepreneurial team is an opportunity for vocational education to develop its training business, and it is also a reflection of the realization of social value in vocational education.

\section{REFERENCES}

[1] Liu Ying, Analysis on the Ways and Policy Driven Mechanism of Accurate Poverty Alleviation in Vocational Education [J] Modern Business Trade Industry, 2018. (in Chinese)
[2] Zhang Yusong, Li Yunfei, Vocational Education Promotes Accurate Poverty Alleviation Research from the Perspective of Vocational Education Group [J] Education and Vocation, 2018, 13. (in Chinese)

[3] Xun Ge, Research on the Status Quo and Countermeasures of Rural Innovation and Entrepreneurship under the Rural Revitalization Strategy [J] Rural Economy and Science-Technology, 2018, vol. 29, 17. (in Chinese)

[4] Nian Meng, The Current Situation and the Policy Proposal of Rural Innovation and Entrepreneurship in China [J] Journal of Chongqing Institute of Technology, 2018, vol. 32, 8. (in Chinese) 